\section{Experiential Learning Experiences to Enhance Preservice Special Educators' Literacy Instruction}

\author{
Marie Tejero Hughesa, Gina Braun ${ }^{b}$
}

\begin{tabular}{ll}
\hline Received: & 17 May 2019 \\
Revised: & 13 September 2019 \\
Accepted: & 16 September 2019 \\
ISSN: 1307-9298 & Copyright @ IEJEE \\
www.iejee.com
\end{tabular}

DOI: 10.26822/iejee.2019155341

\begin{abstract}
We must provide preservice special educators with quality programs that are inclusive of both the knowledge and skill needed for delivering engaging and impactful literacy instruction. Successful teacher education programs not only engage preservice educators in developing their knowledge of practices but provide opportunities to practice and reflect on teaching students with disabilities. Thus, the purpose of this study was to examine if participation in an experiential learning experience that was integrated into literacy course enhanced preservice special educators' knowledge of literacy instruction, shifted their beliefs, and/or modified their practice for working with students with disabilities. Over three semesters, 47 preservice special educators enrolled in the course and completed the experiential learning experience. We conducted a qualitative content analysis of the lesson plans and reflections that these preservice educators submitted throughout the course. Our findings revealed that the preservice educators not only increased their instructional knowledge but as they engaged with students with disabilities, they changed their instructional practices, utilizing more evidence-based practices and shifted their beliefs by holding themselves accountable for student learning, These findings reaffirmed the continued need to integrate experiential learning throughout preservice programs to allow teachers to put into practice what they are learning in courses.
\end{abstract}

Keywords: Literacy, Special education, Teacher education, Preservice educators, Disabilities

\section{Introduction}

Effective special educators can make a difference in the literacy development and achievement of students with disabilities; therefore, it's key that teacher educators provide preservice teachers with quality programs that adequately prepare them to teach literacy to this population. However, determining what preservice special educators need to be effective in the classroom is challenging for faculty given the wide range of literacy needs students with disabilities may have (Author, 2017). Furthermore, additional challenges of special educators including role ambiguity (Shepherd, Fowler, McCormick, Wilson, \& Morgan, 2016), teaching in inclusive environments (Shin, Lee,\& McKenna, 2016), and implementing intensive interventions (Vaughn, Denton, \& Fletcher, 2010), contribute to the continued need for us to examine and redesign our teacher preparation programs to meet these evolving responsibilities. In particular, special educators require a deep knowledge base in both general education curriculum and in adapting the curriculum to meet the multiple needs of learners (Leko, Brownell, Sindelar, \& Kiely, 2015); thus, teacher education programs need to reflect this. Also, our special education preparation programs must structure opportunities for preservice educators to practice teaching in the field and reflect on their practice and student learning (Lacina \& Block, 2011).

Experiential learning is recommended as an essential component of special educator preparation (Leko et al., 2015); however, little research has been done examining the impact these experiences have on the development of preservice special educators' knowledge and practice. Furthermore, while there is much literature examining specific models of teacher preparation programs, the focus has been primarily on the preparation of general educators (Risko et al., 2008) with minimal research documenting how best to prepare special educators to meet their ever-increasing teaching demands (Brownell, Sindelar, Kiely, \& Danielson, 2010). Researchers have proposed an experiential learning model for assisting future special educators in learning the appropriate skills and strategies to be prepared to teach their students (Leko et al., 2015), but there continues to be a lack of research, self-study, or reflection on the best approaches to integrate these experiences as part methods courses designed for preservice special educators.

\section{Experiential Learning in Literacy}

To bridge the research to practice gap in teacher preparation and classroom practice, scholars are prioritizing models reflecting experiential learning theories for teacher education (DeGraff, Schmidt, \& Waddell, 2015). Simply put, as preservice educators engage in real experiences with students, the knowledge they gain in courses is transformed as an outcome of the experience (Kolb, 2014). These experiences also need to include a cyclical model that engages the educator in concrete practices, reflective observation, abstract conceptualization, and active experimentation (Kolb, 2014). Also, components such as the explicit modeling of instructional practices, opportunities for application, and immediate feedback support an experiential model for teacher preparation (Author, 2008; Leko et al., 2015). While several frameworks exist supporting experiential learning, few have focused on how to incorporate this learning to prepare special educators to meet the literacy needs of children with disabilities.

In an experiential-based model, based on the science of learning, the coursework is grounded in research and paired with opportunities for preservice special educators to practice both in the university classroom and the field early in their preparation. Specifically, teacher educators have indicated that providing the preservice special educator with opportunities to engage in structured one-on-one instruction with students with disabilities enhances their teaching abilities and confidence (e.g., Spear-Swerling, 2009). Finally, 
research also supports the importance of providing opportunities for preservice educators to receive immediate feedback and to engage in reflection both, which lead to successful teacher preparation (Moon, 2013).

Although research shows that preservice educators benefit from experiential learning, creating a well-designed literacy course that provides meaningful experiences is challenging (DeGraff et al., 2015). Moreover, adequately preparing special educators to teach literacy to learners with disabilities from underserved communities requires additional factors (e.g., impacts of poverty) to address; thus, creating further challenges for teacher educators to contemplate when developing a literacy course. Therefore, as teacher educators, we need to consider how to address each of the following components: evidence-based literacy practices (e.g., Al Otaiba, Lake, Scarborough, Allor \& Carreker, 2016), experiential-based assignments (DeGraff et al., 2015; Zeichner, 2012), and reflective practices (Boody, 2008) within our courses.

Evidence-based literacy practices. Evidence-based practices (EBP) refer to instructional strategies or interventions that demonstrate positive outcomes for students based on quality research that meets the "gold standard" (Odom et al., 2005). Literacy EBPs include instructional practices and strategies such as explicit instruction (Rupley, Blair \& Nichols, 2009) and specific interventions and programs (Vadasy \& Sanders, 2008). Several resources are available such as the United States (US) What Works Clearinghouse and the National Center on Intensive Interventions, that provide educators with information about EBP including its level of effectiveness and age groups for which it is designed for Overall, educators agree that effective implementation of evidence-based practices will increase student outcomes; however, the success of such requires practices that depend heavily on teachers' access, knowledge, and implementation of the practices (Cook \& Odom, 2013). To facilitate teachers' preparation, literacy courses should be grounded in a strong literacy knowledge base to ensure preservice educators are knowledgeable of best practices (Castles, Rastle, \& Nation, 2018). The development of content for preservice educators is thus grounded in research-based theories and practices that increase their background knowledge on the evidence-based practices for instructing literacy (Rock et al., 2016). Therefore, an effective literacy course lays a foundation of knowledge that includes an overview of literacy development, information on evidence-based practices, and discussion of effective instructional strategies and assessments to support the diverse needs of students with disabilities (Lacina \& Block, 2011).

Beyond basic knowledge and skills connected to literacy content, preservice special educators also require additional support in building knowledge around the common characteristics of diverse struggling students and how to adapt literacy instruction to meet these individual needs (Brownell et al., 2010). Furthermore, for preservice educators to successfully work with students who come from different backgrounds, socioeconomic class, or race, they need to be provided with the tools and strategies to meet the needs of all learners (Zeichner, 2012). Thus, as the expectations and demands grow to meet the diverse needs of students, literacy courses cannot be solely focused on evidence-based teaching practices, but on preparing educators to use and adapt these practices for these diverse students.

Experiential based assignments. While meaningful and well-developed coursework is a necessary and invaluable component to preparing special educators, courses, including those early in the program, also need to integrate tightly aligned experiential-based assignments (Zeichner, 2012). Teacher preparation programs need to provide applicable real-life opportunities to practice new knowledge and skills which will then enhance their preservice educators' readiness and instructional practices. This is particularly true in learning to teach literacy given that it is a situated practice that requires preservice educators to engage in the field working with students and to think critically by posing and solving problems (Cochran-Smith et al., 2015). Although there is continued debate as to how much fieldwork is required of preservice educators, we know that providing opportunities to practice in situated experiences impacts their knowledge and practice (Leko et al., 2015).

The quality of these early experience and how it aligns with the coursework matters (Hail, Hurst, Camp, \& Laughlin, 2015). Experiential learning can take various shapes and forms including one-on-one structured sessions with students with disabilities which allows preservice teachers to practice what they have learned and reflect on their instruction (Haverback, \& Parault, 2008; Spear-Swerling, 2009). Preservice educators can take strategies and tools learned during their coursework and apply it directly in the field, by only focusing on one student, they can truly experience the cyclical process of teaching, including collecting data before, during, and after teaching, providing instruction, and adapting along the way to meet the individual needs of their student (Al Otaiba, Lake, Greulich, Folsom, \& Guidry, 2012). As preservice educators engage in the one-on-one instructional experience while taking a literacy course, their literacy knowledge increases, misconceptions are dispelled, and the students they work with improved their literacy development (Spear-Swerling, 2009).

Reflective practice. Reflection on practice and student work is a critical component for preparing educators to teach literacy to students with disabilities successfully. It is vital for preservice educators to reflect on students' learning and progress; thus, they need opportunities to reflect on their planning and instruction by collaborating with peers (DeGraff et al., 2015). Like experiential experiences, reflective practices have been examined in a variety of ways, from a professor, mentor teachers, and peers' discussions (Author, 2008), video collection (Nagro, deBettencourt, Rosenberg, Carran, \& Weiss, 2017), and even microblogging (Yang, 2009). Regardless of the method used, encouraging preservice special educators to reflect on their experiences enhances the quality of the instruction, since at first many preservice educators focus primarily on motivation and student choice, but with practice and reflection move into building the student confidence and increasing the students' comprehension through introducing skills and strategies (Zeichner \& Liu, 2010).

\section{Purpose of Study}

Although research on literacy instruction for students with disabilities has moved the field towards a better understanding of what effective literacy instruction and teacher preparation for meeting the needs of students with disabilities is, there is still a great deal uncertainty on how to transfer this research into the classroom (author, 2017). As advances in literacy instruction for students with disabilities have progressed, the time teachers spend during literacy instruction focusing on the specific needs of students with disabilities continue to remain inadequate (Brownell \& Leko, 2014). In part this may be because the pedagogical knowledge related to literacy for this population is not as well defined (Phelps, 2009), which in turn may explain why new special educators struggle to carry out the complex pedagogical practices needed to support their students (Brownell et al., 2009). If special educators are to success- 
fully provide the instruction students with disabilities need in literacy, it is imperative that their practice of teaching literacy be not only be grounded in the knowledge base of literacy, but in also know how to flexibly use this knowledge.

Therefore, special education teacher preparation programs need to have a stronger focus on establishing, as Ball and Forzani (2009) proposed for teacher education, a practiced-based curriculum to prepare special education teachers for literacy instruction. By using a practice-based curriculum to prepare special education teachers to teach literacy to students with disabilities allows for "...repeated opportunities for novices to practice carrying out the interactive work of teaching and not just to talk about it." (Ball \& Forzani, 2009 , p. 503). Special education teacher education programs can provide these opportunities for preservice educators to practice their craft in numerous ways including conducting demonstration lessons (Hatch \& Grossman, 2009) and participating in experiential learning experiences (Leko et al., 2015) throughout their preparation programs. By engaging in these opportunities, they can receive feedback and guidance from their peers, collaborating teachers, and faculty (Lampert \& Graziani, 2009).

Incorporating these opportunities in the core of special education teacher education program could prepare preservice special educators to carry out essential elements of literacy practice in ways that reflect what researchers have identified are important fundamentals of good teaching, that is, explicit instruction and modeling (author, 2017). However, there is not extensive research available examining how these practice-based activities, particularly, early experiential learning experiences, can impact preservice special educators' teaching of literacy. Thus, there is a need to take a closer look at how special education teacher preparation programs are including a practice-based curriculum and the impact it may have on the development of preservice special educators' literacy instruction for students with disabilities. Since we had recently redesigned a literacy course in our special education program to include a greater focus involving students in experiential learning experiences and reflective practices, we decided to look closely at how an experiential learning experience (one-on-one literacy instruction with a child with disabilities) that was integrated into our literacy course influenced the teaching and planning of the preservice special educators enrolled. We were particularly interested in learning how this experience may have: a) enhanced their knowledge of instruction; b) influenced their instructional practices over time; and c) impacted their beliefs about how students with disabilities learn.

\section{Methodology}

\section{Participants}

Preservice educators $(n=47)$ in our master's special education preparation program at a large, urban university in the US participated in this investigation which was approved by the university's Institutional Review Board. The majority of graduate students did not have backgrounds in education were process of obtaining their initial special education teaching endorsement. These preservice educators were enrolled in their first literacy methods course which typically is taken during the first year in the program. The special education department offers one section of the course each semester, and all preservice special educators enrolled across three semesters participated in the study. Data from three additional students who were enrolled in the course was not included in the analysis due to not completing the course assignments that were reviewed. Approximately $79 \%$ of students in our program are female, and the racial and ethnic background of the students include White $77 \%$, Hispanic 15\%, Black/African American 3\%, Asian 3\%, unknown $2 \%$, and Multi-Race $1 \%$.

\section{Procedures}

Course. Preservice special educators were enrolled in a required literacy methods course, taught by the first author, which focused on developing their knowledge and skills around evidence-based practices for literacy instruction for elementary-aged students with disabilities. This literacy course is the first of two required in the special education program which consists of 33 credits of coursework and an additional 13 credits related to internship and student teaching. This first literacy course emphasizes the components of designing, implementing, and assessing literacy instruction for elementary students with disabilities. The course covers a range of literacy topics (e.g., literacy development) and components (e.g., phonics, vocabulary). In addition, preservice educators were introduced (e.g., modeling, videos, review of programs/curriculum) to EBP that are effective for particular types of students with disabilities to enhance their literacy development. The preservice educators were required to complete several assignments related to the topics of the course, such as demonstrating explicit instruction lessons and conducting an interactive read-aloud lesson by interacting with their peers within the university classroom.

Experiential learning experience. All preservice educators completed a 15-hour experiential learning experience as part of the course where they worked with a student with a disability to assesses their literacy development and provide individualized instruction. As with most of experiential experiences preservice educators are required to complete as part of their coursework during the first part of the program, preservice educators make their own placements and identify a special educator at the placement site to service as their cooperating teacher. The experiential learning experiences primarily took place in public elementary schools in a large metropolitan area located in the Midwest of the US, but a few experiences took place in specialized settings (e.g., private school for students with disabilities). Preservice educators worked with students that were enrolled in 1st to 5th grade (age 6 to 11) and were identified by the schools as receiving specialized services for a range of disabilities, mostly for learning disabilities, autism, and mild intellectual disabilities. Preservice educators worked individually with the student for up to five hours to learn more about them and assess their literacy interests and achievement levels (e.g., informal reading inventory, interest inventory). Afterwards preservice educators provided 10 one-hour lessons that were conducted one-on-one with the student and focused mostly on a literacy area they determined the student needed further instruction in (e.g., short vowel sounds; identifying main idea). These individualized literacy lessons were conducted over the course of the semester. Assignments related to this experience included assessing the students with informal measures, designing lesson plans, writing reflections, and creating a case study report.

Throughout the semester, the preservice educators designed literacy lessons which they implemented with an individual student and followed each lesson with a written reflection of their instruction. As they completed a session with the student, preservice educators uploaded their lessons plans and reflections to an online journal and received written feedback from the instructor along the way. The feedback focused on both their lesson plan development and reflection on instructional practices and student outcomes. The instructor gave explicit feedback on ways to enhance the lesson as well as provided guiding question to help the preservice educator think critically about their instruction. In addition, most of the preservice educators completed their experiential learning experience under the supervision of cooperating teachers who worked in highly diverse schools. The cooperating teacher periodically also provided the preservice educator with oral feedback regarding their lesson plans. In addition, preservice educators digitally recorded 
two lessons and shared the video with their peers and the instructor, thus receiving both oral feedback about their instruction based on the videos as well.

During the experiential learning experience, the pre-service educators typically worked with their student in the back of the classroom or a small separate setting, such as an empty resource classroom. Preservice educators were provided with a lesson plan template to follow which included identifying the learning standard and lesson outcome, describing the lesson activities, and outlining the materials used. They were also provided with questions to facilitate their reflections (e.g., What did you do to support student engagement in the tasks? How did you build connections between the student's prior learning and experiences and new learning?). The preservice educators concluded the experience with a case study report summarizing the sessions with the students, including anecdotal and curriculum-based measured data. The case study reports were shared with the teachers and families of the students to highlight the progress the students had made and recommendations for future instruction.

Data sources. All the lesson plans and reflections were downloaded from the course online journal at the end of semester and de-identified before analysis. For each of the three semesters the 10 lesson plans and their corresponding reflections which preservice educators submitted were analyzed. In total there were 470 lessons plans and reflections included in the analysis.

Data analysis. We utilized qualitative content analysis, one of the oldest established methods to analyze texts (Mayring, 2014), to examine the assignments and determine how our course may have enhanced preservice educators' knowledge and skills related to literacy and students with disabilities. Qualitative content analysis is strictly controlled methodologically, and that allows the data to be analyzed step-by-step. Central to it is a category system which is developed right on the material employing a theory-guided procedure (Kohlbacher, 2006). For this examination, we utilized an inductive analysis using all of the data collected to develop common categories across the data sources. We began with the purpose for this research and worked through the first few lesson plans then the reflections. Throughout this process we summarized and reorganized notes, read data sources, drafted memos, coded data, compared and contrast codes, negotiated codes, developed themes from the codes, and created matrixes of the identified themes. We worked through this process using collaborative online documents and regular research meetings and continued to negotiate until we had complete agreement on the final themes. Once the final categories were established, one researcher coded the remaining lesson plans and reflections, then the second researcher reviewed the coding for reliability purposes, when there were disagreement researchers discussed the item and negotiated the final result (Mayring, 2014). Triangulation of the data sources was conducted throughout by continuously revisiting the documents to revise and corroborate the finding. To effectively use inductive qualitative analysis, open-coding was used on each of the data collection tools (Corbin \& Strauss, 2015). Given the importance that states and school districts in the US place on educators addressing state learning standards in their instruction (see www.corestandards.org for examples of literacy standards), lessons were also analyzed for alignment of these state learning standards in literacy to outcomes and lesson activities, as well as strategies that were chosen. Also, reflections were also reviewed to gain insights into the preservice educators' thinking about the choices they made.

\section{Findings}

Four major themes emerged from the data we looked at that indicated that over the course of the semester preservice special educators: a) increased their instructional knowledge; b) changed their practice; and c) shifted their beliefs. Finally, while the data showed preservice educators' growth, the final theme that emerged showed that educators had d) continued challenges.

Increased instructional knowledge. Looking at the lesson plans and reflections from the start of the semester to end, it was evident that the preservice educators increased their knowledge related to providing literacy instruction to students with disabilities.

Student supports for success. Throughout the semester, the preservice educators showed increased knowledge of their student's needs. Simultaneously, they increased their knowledge of what supportive strategies the students needed to grasp new concepts. Academic strategies ranged from prompting to use of graphic organizers and sentence stems. As an example, during lesson one, a preservice educator noticed their student was not reading with expression; "I would like to see improvement in excitement when he sees an exclamation point." This concern continued through lesson three, after reflecting, she decided to "...provide sentence strips with question marks and exclamation marks. After modeling, we will record how I sound when I say them and then record him [the student] so he can hear himself." As this example shows, the preservice educator used the knowledge of the student struggle and knowledge of supportive strategies to intentionally practice and repeat new skills in a variety of ways.

There was a great deal of evidence showing the preservice educators' knowledge of the student was built through meaningful relationships. The preservice educators went from having students complete a general literacy interest inventory to genuinely building relationships with the students; not only through progress monitoring but by having meaningful conversations and effort to understand the students' frustrations and what motivated them. To illustrate, a preservice educator was having a difficult time engaging the student in the texts used for instruction, thus, upon taking the time to talk with the student more, she determined that the student had recently gotten glasses; therefore, the preservice educator found a book Who Wears Glasses in an attempt to engage and excite the student. Similarly, another preservice educator stated that the "student does not like to read, in part because she has not found a book that interests her...". The preservice educator then discovered that the student liked mysteries and found mystery books at her level and stated, "I was delighted that she loved the R.L. Stine book Rotten School Dudes, The School Is Haunted. At pick up, she asked her mom to take her to the library so that she could check out the rest of the books in the series."

Likewise, gaining knowledge in student and supportive strategies, the preservice educators made changes in their behavioral supports for students. Many preservice educators, for example, discussed that students would be intrigued by certain activities, but once they got to components that were a bit more challenging, the student tended to shut down or get distracted. Thus, many preservice educators began to embed more breaks and allowed the students to choose a short, engaging activity. Similarly, many of the preservice educators increased knowledge utilizing games that were not only engaging but supported the learning of new skills. As this preservice educator noted, she began using hands-on word sorts and increased 
engagement by making the game teacher vs. student. She reflected that the student "changed his mood and was motivated and enjoyed the game."

Furthermore, more than half of the preservice educators showed an increased knowledge on how to build up student confidence. These preservice educators reflected on student confidence and how it directly impacted their engagement in the instruction for that day, leading to more intentional strategies to help increase student confidence. To illustrate one preservice educator struggled a great deal in the beginning with their student, since the student would often shut down and refuse to work or read the books. At the end of the sessions, the preservice educators reflected that:

She [the student] has mentioned a few times how much she does not like reading books that are 'too hard.' I believe she becomes embarrassed when she cannot pronounce many of the words in a particular book, so I always make sure to provide her with reading material she is either familiar with, or that is on her level so she can easily decode.

Literacy knowledge. Looking at the work across the semester, it was clear that the preservice educators were becoming more comfortable and confident with the literacy content. Many of the preservice educators showed an increased knowledge of the standards as well as writing outcomes that align with the learning standards. At the beginning of the semester, most of the preservice educators were unable to align the standard to the outcomes which were apparent in their lack of understanding of the standard. By the end, all preservice educators showed tighter alignment across standards and outcome. Additionally, preservice educators showed an increase in their knowledge of early literacy skills such as phonics and phonemic awareness. For example, one preservice educator began the semester stating they were teaching phonics by having the student "state rhyming words, and blend and segment words verbally;" however, these practices are more aligned with phonemic awareness. By the end, there was an accurate distinction between her instruction of phonics and phonemic awareness skills.

Instructional practices. The preservice educators demonstrated increased knowledge of effective instruction. At first, several preservice educators used worksheets or solely had students read to them without any instruction attached. As an example, during lesson one, a preservice educator wrote "the student read the book to me, and I would help them with a word when they got stuck," and that was the extent of the instruction. By the end, the same educator was modeling reading fluency to the student and embedding decoding work. As the semester progressed, there were many instances of effective instructional practices during each session, including direct instruction, guided practice, modeling, questioning, and providing feedback.

Change in practice. Preservice educators began using more evidence-based practices, and their practice changed in part to their use of assessments to drive their instruction.

Use of evidence-based practices. As the semester evolved, so did the preservice educators use of evidence-based practices. Preservice educators moved from teaching lessons that included a random mix of activities that did not appear to have direct connections to the needs of the student, to become more intentional about the skills and strategies selected. Likewise, for the most part, none of the skills introduced to the students were taught directly by the preservice educators at the start, but instead they appeared to focus on presenting activities related to the skill they had decided to work on and did not present a cohort lesson focused on developing the literacy areas the student needed supports in. Over the semester, most preservice educators moved from activities such as worksheets to increasing students' understanding of texts by using strategies such as Question Answer Response and ReQuest.

Similarly, to several of her colleagues in the course, this preservice educator's lessons showed how lessons evolved. At the start of the semester she designed lessons that were mostly a collection of activities, such as introducing many new sight words that the student read through one time, discussing some decoding strategies, then moving into echo reading with a text not aligned to interest, instructional level, or previous activities and then answering basic questions about main idea. Across these different skills and strategies presented in the lesson, there was no fluidity, connections, or purpose to each. Also, the preservice educator did not use any instructional strategies; instead, each activity was just presented as something for the student to complete. The same preservice educator then showed a good turnaround in that later on as she began to reduce the amount of varied activities and focused more planning meaningful lessons with the use of principles of explicit instruction. For example, she started by modeling fluent reading of an instructional level text and provided opportunities to practice with the use of repeated reading. In reflecting on the repeated reading strategy, the preservice educator mentioned: "She [the student] really enjoyed the poem, and when I asked her to read sections back to me she mimicked my tone and inflection well."

Similarly, while another preservice educator did not begin their lessons with mix-matched skills, she did not engage in any direct teaching. For example, this preservice educator started the first few sessions having a student read a text, and then the student was asked comprehension questions to culminate the lesson. Reviewing her reflections and lessons plan, few details showed any evidence that she was teaching or encouraging any reading comprehension strategies to increase independence and understanding at the beginning, but there was a definite switch by the end of course. By lesson 10, the preservice educator reflected, "I decided to use only one text for the entire lesson so that we could do several things with it. I can see that teaching strategy is starting to help him understand what he is reading." Overall, preservice educators showed how their changes in practice became more intentional and useful for the students.

Use of assessment to drive instruction. Whether done correctly or with intention, it was evident throughout the sessions that all the preservice educators were considering student progress as they planned instruction; however, most of them did not use assessment data to start. In the beginning, most decisions were made based on something that happened once in a session without true evidence. Towards the end of the sessions, the preservice educators showed more intentionality in using student evidence and reoccurring anecdotal notes to drive instruction. Many of the reflections earlier on were similar to this preservice educator, "I think the student needs to work on decoding;" however, later on, he was more specific on how the student was doing and the reason for changes:

I administered the CBM [curriculum-based measure] with this reading passage, and his reading rate was significantly below the target level. The passage was a borderline 2 nd grade/3rd-grade reading passage, so it was right at his instructional level. However, the score said otherwise; he was clearly at frustration. Going forward, we will not be using the reading passages from Reading A-Z anymore, as I have completed the process of checking out the book that he is reading to plan instruction on my own.

Shift in beliefs. It was noticeable that preservice educators began to shift their beliefs related to how students learn, as 
well as what was their role as an educator.

How students learn. With more confidence, development of their practice, and relationship with their students, the preservice educators' reflections showed a shift in the belief of student learning, by reflecting less about student behavior to focusing more on how the quality of their plans and instruction enhanced student learning. They began to take the responsibility off of the students for "not knowing" or "acting out," and more on their instructional practices and how they as teachers were responsible for their students' learning. As can be seen in this preservice educator later lesson reflection, "I chose to teach this to my student because he missed questions that required knowledge of key details on the CBM I administered. I am beginning this intervention by teaching organizational strategies for comprehension."

Role as an educator. It was evident in their reflections that the preservice educators shifted their beliefs regarding their role and responsibilities in ensuring student success. From the beginning of the semester to the end, the preservice educators spent less time reflecting on what the students could not do and more on what they as educators could do to increase positive outcomes. For example, one preservice educator at the beginning was more inclined to blame the student for not grasping concepts or solely focus on what the student was unable to do, "... she forgotten how to fill it out," or "...the student was unable to answer their questions." However, towards the end, the preservice educator shifted her belief and recognized student success was based on their instructional decisions by writing comments such as, "my primary concern about the lesson is that I did not explicitly model the questioning strategy...".

Continued challenges. While preservice educators showed much growth, some common challenges were still evident in their final case study reports, including struggling to select strategies when increasing rigor and continued misconceptions on progress monitoring.

Struggling to select strategies when increasing rigor. As mentioned, most preservice educators became more intentional about what they taught and began to increase rigor as they developed more knowledge of literacy. However, once they got to a certain point of rigor, it was difficult for some of the preservice educators to select the appropriate instructional strategies to support their students. Also, some who saw progress in their student's skills such as retell and main idea, continued with those skills as opposed to increasing rigor and moving on to skills such as inferencing. For example, one preservice educator focused on the main idea throughout the sessions; however, used the same strategy each week, even though the student was not making progress. She would read a text and ask the student to complete a graphic organizer. Finally, when the preservice educator realized the student was not making progress on this skill, in lesson nine, she switched to decoding words and struggled to find the strategies to support the student in identifying the main idea and moving forward with comprehension.

Continued misconceptions of progress monitoring. While most preservice educators showed growth in their literacy practices, some continued to have misconceptions on how best to progress monitor. Some preservice educators, for example, would choose a CBM that was not aligned with the goal of the session - demonstrated when a preservice educator reflected on a student's progress of decoding long vowel words after administering fluency passages or when another educator used sight words lists to monitor fluent reading growth or lack thereof.

\section{Discussion}

Through our content analysis of preservice special educators' lesson plans and reflections from the course, the findings showed that future special educators had experienced growth in their literacy instructional practices and beliefs about learning and teaching as they participated in an experiential experience that was part the literacy method course for diverse learners. Through their opportunities to engage in experiential learning, there was clear evidence in both the lesson plans and reflections, that preservice educators not only increased their content knowledge, including specific supports and literacy content but also became knowledgeable on how to apply this information (Amolloh, Wanjiru, \& Lilian, 2018). We know that merely teaching about evidence-based practices is not adequate preparation for teaching and that preservice teachers who are knowledgeable about practices are not always able to translate this knowledge to high-quality instruction (Brownell et al., 2009). Thus, this increased amount of time preservice special education teacher spent in the field instructing students early on in their program assisted in bridging the gap between the knowledge they learned in the course and their ability to apply this knowledge with students with disabilities (Leko et al., 2015). As the preservice educators gained experience working with students, they began to automatization some of the basic teaching behaviors which in turns freed up their cogitative resources to allow for more complex problem solving, which is much needed when meeting the unique needs of individual students with disabilities (Wolff, Jarodzka, \& Boshuizen, 2017).

In addition, the course assignments reviewed showed that there were changes in preservice teachers' literacy practices as evidenced by the differences in their early lesson plans and reflections when compared to those submitted later in the semester. In particular, their instructional practices became much more focused on using evidence-based practices and in the use of assessments to drive instruction. Although many teacher preparation programs introduce evidence-based literacy practices in their courses, preservice educators are not receiving the practice or feedback they need to develop their use of these practices (Janssen, Grossman, \& Westbroek, 2015). Ideally, feedback on teaching practice is most effective when delivered immediately (Sweigart, Landrum, \& Pennington, 2015); however, this may be difficult to accomplish in a course that is outside the student teaching experience. Thus, the preservice special education teachers in the course were immediately applying what they learned in the course, and then we regularly provided feedback during in-class activities and through their online lesson plan journal, which allowed them to make adjustments to their instruction based on this ongoing guidance. This ongoing feedback and mentoring was critical to change their teaching behavior which in turn strengthened their instruction with children (Dağ \& Saro. 2017; Schütze, Rakoczy, Klieme, Besser, \& Leiss, 2017). Similar findings demonstrated that preservice educators who had opportunities to participate in field experiences with ongoing feedback from university supervisor and peers while enrolled in the content course better prepared them to teach by increasing confidence on selecting and implementing quality instruction (McDonnough \& Matkins, 2010). Teacher educators must consider opportunities to provide preservice educators with meaningful and contextual feedback to enhance their pedagogy and practice.

Finally, there was evidence of shifts in preservice educators' beliefs both in how students learn and their role as educators. Similar to the findings in Wozencroft, Pate, and Griffiths (2015), the pre-service educators perceived students with disabilities changed over the course of the se- 
mester throughout their experiential learning experiences. Although the review of assignments showed that progress was made in several areas, not surprisingly given that preservice special educators were early into their preparation program, there continued to be some challenges amongst them on how to meet all the individual literacy needs of their students with disabilities. Therefore, we discussed the need to increase the amount of structured experiential experiences the preservice teachers engage early in the program to better prepare them for internship and student teaching and provide them opportunities to refine their instructional skills (Janssen et al., 2015). These experiential experiences should be a fundamental and integrated aspect of a special education teacher preparation programs; thus, we need to identify opportunities for deliberate practice throughout the program to help facilitate the development of teaching skills (Sayeski, Hamilton-Jones, Cutler, Earle \& Husney, 2019).

\section{Implications}

This review of our preservice educators' assignments in our literacy course has several implications for our special education teacher preparation program. Participating in experiential experiences early in a teacher preparation program appears to be valuable for our preservice special educators since it assisted them in developing their knowledge, skill, and beliefs about instruction. Preservice educators need to not only have repeated exposure to the content they are learning, but also need to have opportunities to actively retrieve this knowledge as they engage in practice with students (Brown, Roediger, \& McDaniel, 2014). We encourage teacher educators, as we are doing ourselves, to create experiences that allow preservice special educators to engage with students with disabilities and begin to develop their craft from their first semester in a program. We know that meaningful practice in teaching students can be taught during early coursework in teacher preparation programs (Sayeski et al., 2019) thus, these experiential experiences should be integrated into all courses throughout the program, rather than clustered at the end during practicum and student teaching experiences which is typically the norm. Although special education teacher preparation programs typically note that preservice educators complete several hours in the field before student teaching, the vast majority of these field experiences tend to be observational in nature or unstructured. Therefore, by designing structured experiential experiences that allow preservice educators to apply the knowledge they are gaining in coursework in their work with students with disabilities allows them to develop their teaching practices. These experiential experiences are a valuable component of a teacher preparation program, even though preservice educators may struggle with some areas of instruction during them, as the preservice educators did in this study. Therefore, it is beneficial to not only continue these types of structured experiential experience throughout our program to build preservice educators' teaching repertoire and confidence but to plan these experiences systematically, to build off of each other. Thus, we are engaged in conversations with our colleagues to review the various assignments and experiences required in courses to develop a more systematic plan.

Besides taking part in the experiential experience of providing individualized instruction to a student with disabilities, the preservice educators in the course received ongoing feedback in multiple ways. Key to any experience in teaching is the continued and ongoing feedback of preservice educators' lesson plans and instruction from peers, mentors, and professors. This feedback helped support preservice special education teachers in their selection of instructional strategies and practices in real-time. Just as performance feedback is usually provided to preservice educators during their student teaching (Cornelius \& Nagro, 2014), we also need to build a process for preservice educators to reflect and pro- vide avenues for them to receive feedback. However, unlike classroom experiences later on in their teacher preparation program (e.g., student teaching), the majority of these experiential experiences linked to courses may not have direct university supervisors, but instead, rely more on the support of the cooperating teacher. Therefore, it is up to the course faculty to systematically integrate cycles of practice and feedback into their courses, since research shows that frequent opportunities to practice and receive feedback can improve the efficiency with which preservice teachers acquire and implement practices accurately (Peeples et al., 2018; Sayeski et al., 2019).

Because we know the importance of preparing and retaining quality and effective special educators, the responsibility to adequately prepare and keep teachers in classrooms has largely been put on teacher education programs by teacher leaders (Goodwin \& Kosnik, 2013). Thus, we, as teacher educators, must design robust programs that include experiential experiences throughout the program that provide preservice special educators with a strong literacy knowledge base (Aşikcan, Pilten, \& Kuralbayeva, 2018), as well as practical experiences that address the unique needs of students with disabilities (Brownell et al., 2010; Rock et al., 2016).

\section{Limitations}

There are several limitations to be considered related to our review of our literacy course and the experiential experience component. Although triangulation was conducted by reviewing lesson plans and reflections, the sample only included preservice special educators from our university who took the course across three different semesters with the same instructor. Since a comparison group was unavailable in the same program, teasing out the impact of the course itself was not conducted. Future group comparison research would support in further identifying the effective components of literacy methods courses for preservice special educators. Lastly, given that the focus of the research was on students' perspectives and engagement, the data consisted solely of students' self-reported data; thus, access to any independent observation of their instruction was not available. Therefore, to expand on this work, future observation research of preservice special educators' practice would provide additional information such as their strengths or misconceptions to further support the development of preparation programs.

\section{References}

Al Otaiba, S., Lake, V. E., Greulich, L., Folsom, J. S., \& Guidry, L. (2012). Preparing beginning reading teachers: An experimental comparison of initial early literacy field experiences. Reading and Writing, 25, 109-129.

Al Otaiba, S., Lake, V. E., Scarborough, K., Allor, J., \& Carreker, S. (2016). Preparing beginning reading teachers for K-3: Teacher preparation in higher education. Perspectives on Language and Literacy, 42(4), 25-32.

Amolloh, O. P., Wanjiru, K. G., \& Lilian, G. K. (2018). Workbased Learning, Procedural Knowledge and Teacher Trainee Preparedness towards Teaching Practice at the University of Nairobi, Kenya. International Journal of Learning, Teaching and Educational Research, 17(3), 96-110.

Aşikcan, M., Pilten, G., \& Kuralbayeva, A. (2018). Investigation of reflecting reading comprehension strategies on teaching environment among pre-service classroom teachers. International Electronic Journal of Elementary Education, 10(4), 397-405.

Ball, D. L. \& Forzani, F.M. (2009). The work of teaching and the 
challenge for teacher education. Journal of Teacher Education, 60(5), 497 - 511.

Boody, R. M. (2008). Teacher reflection as teacher change, and teacher change as moral response. Education, $128,498-506$.

Brown, P. C., Roediger, H. L., \& McDaniel, M. A. (2014). Make it stick: The science of successful learning. Boston, MA: Belknap Press.

Brownell, M. T., Bishop, A. G., Gersten, R., Klingner, J. K., Penfield, R. D., Dimino, J., ... Sindelar, P. T. (2009). The role of domain expertise in beginning special education teacher quality. Exceptional Children, 75, 391-411.

Brownell, M. T. \& Leko, M. M. (2014). Preparing special educators to teach literacy. In P. T. Sindelar, E. D. McCray, M. T. Brownell, and B. Lignugaris/Kraft (Eds). Handbook on research on special education teacher preparation (pp. 255-270). NY, NY: Routledge.

Brownell, M. T., Sindelar, P. T., Kiely, M. T., \& Danielson, L. C. (2010). Special education teacher quality and preparation: Exposing foundations, constructing a new model. Exceptional Children, 76(3), 357-377.

Castles, A., Rastle, K., \& Nation, K. (2018). Ending the reading wars: Reading Acquisition from Novice to Expert. Psychological Science in the Public Interest, 19(1), 5-51.

Cochran-Smith, M., Villegas, A. M., Abrams, L., Chavez-Moreno, L., Mills, T., \& Stern, R. (2015). Critiquing teacher preparation research: An overview of the field, part II. Journal of Teacher Education, 66, 109-121.

Cook, B. G., \& Odom, S. L. (2013). Evidence-based practices and implementation science in special education. Exceptional Children, 79, 135-144.

Corbin, J. \& Strauss, A. (2015). Basics of qualitative research: Techniques and procedures for developing grounded theory. Thousand Oaks, CA: Sage.

Cornelius, K. E., \& Nagro, S. A. (2014). Evaluating the evidence base of performance feedback in preservice special education teacher training. Teacher Education and Special Education, 37, 133-146.

Dağ, N. \& Sari, M. H. (2017). Areas of mentoring needs of novice and preservice teachers. International Electronic Journal of Elementary Education, 10(1), 115129.

DeGraff, T. L., Schmidt, C. M., \& Waddell, J. H. (2015). Fieldbased teacher education in literacy: Preparing teachers in real classroom contexts. Teaching Education, 26, 366-382.

Goodwin, A. L., \& Kosnik, C. (2013). Quality teacher educators = quality teachers? Conceptualizing essential domains of knowledge for those who teach teachers. Teacher Development, 17, 334-346.

Hail, C., Hurst, B., Camp, D., \& Laughlin, J. (2015). Preservice Teachers' Perceptions of their Literacy Practicum Experiences. Journal of Reading Education, 40(2), 13-26.

Hatch, T., \& Grossman, P. (2009). Learning to look beyond the boundaries of representation: Using technology to examine teachers (Overview for a digital exhibition: Learning form the practice of teaching). Journal of Teacher Education, 60(1), 70-85.

Haverback, H. R., \& Parault, S. J. (2008). Preservice reading teacher efficacy and tutoring: A review. Educational Psychology Review, 20, 237-255.

Janssen, F., Grossman, P., \& Westbroek, H. (2015). Facilitating decomposition and recomposition in practice-based teacher education: The power of modularity. Teaching and Teacher Education, 51, 137-146.

Kohlbacher, F. (2006). The use of qualitative content analysis in case study research. In Forum Qualitative Sozialforschung/Forum: Qualitative Social Research (Vol. 7, No. 1, pp. 1-30). Institut für Qualitative Forschung.

Kolb, D. A. (2014). Experiential learning: Experience as the source of learning and development. Upper Saddle River, NJ: FT press.

Lacina, J., \& Block, C. C. (2011). What matters most in distinguished literacy teacher education programs? Journal of Literacy Research, 43, 319-351.

Lampert, M. (2012). Improving teaching and teachers: A "Generative Dance"?. Journal of Teacher Education, 63(5), 361-367.

Leko, M. M., Brownell, M. T., Sindelar, P. T., \& Kiely, M. T. (2015). Envisioning the future of special education personnel preparation in a standards-based era. Exceptional Children, 82, 25-43.

Mayring, P. (2014). Qualitative content analysis: theoretical foundation, basic procedures and software solution. Open Access Repository, Klagenfurt (http://nbn-resolving.de/urn:nbn:de:0168-ssoar-395173).

McDonnough, J. T., \& Matkins, J. J. (2010). The role of field experience in elementary preservice teachers' selfDefficacy and ability to connect research to practice. School Science and Mathematics, 110(1), 13-23.

Moon, J. A. (2013). A handbook of reflective and experiential learning: Theory and practice. New York, NY: Routledge.

Nagro, S. A., deBettencourt, L. U., Rosenberg, M. S., Carran, D. T., \& Weiss, M. P. (2017). The effects of guided video analysis on teacher candidates' reflective ability and instructional skills. Teacher Education and Special Education, 40, 7-25.

Odom, S. L., Brantlinger, E., Gersten, R., Horner, R. H., Thompson, B., \& Harris, K. R. (2005). Research in special education: Scientific methods and evidence-based practices. Exceptional children, 71(2), 137-148.

Peeples, K. N., Hirsch, S. E., Gardner, S. J., Keeley, R. G., Sherrow, B. L., McKenzie, J. M., Randall, K. N., Romig, J. E., \& Kennedy, M. J. (2018). Using multimedia instruction and performance feedback to improve preservice teachers' vocabulary instruction. Teacher Education and Special Education, 42(3) 227-245.

Phelps, G. (2009). Just knowing how to read isn't enough! 
Assessing knowledge for teaching reading. Educational Assessment, Evaluation and Accountability, 21, 137-154.

Risko, V. J., Roller, C. M., Cummins, C., Bean, R. M., Block, C. C., Anders, P. L., \& Flood, J. (2008). A critical analysis of research on reading teacher education. Reading Research Quarterly, 43, 252-288.

Rock, M. L., Spooner, F., Nagro, S., Vasquez, E., Dunn, C., Leko, M., ... \& Jones, J. L. (2016). 21st century change drivers: Considerations for constructing transformative models of special education teacher development. Teacher Education and Special Education, 39, 98-120.

Rupley, W. H., Blair, T. R., \& Nichols, W. D. (2009). Effective reading instruction for struggling readers: The role of direct/explicit teaching. Reading \& Writing Quarterly, 25(2-3), 125-138.

Sayeski, K. L., Hamilton-Jones, B., Cutler, G., Earle, G. A., \& Husney, L. (2019). The role of practice and feedback for developing teacher candidate's opportunities to respond expertise. Teacher Education and Special Education, 42(1), 18-35.

Schütze, B., Rakoczy, K., Klieme, E., Besser, M., \& Leiss, D. (2017). Training effects on teachers' feedback practice: The mediating function of feedback knowledge and the moderating role of self-efficacy. ZDM, 49, 475-489.

Shepherd, K. G., Fowler, S., McCormick, J., Wilson, C. L., \& Morgan, D. (2016). The search for role clarity: Challenges and implications for special education teacher preparation. Teacher Education and Special Education, 39(2), 83-97.

Shin, M., Lee, H., \& McKenna, J. W. (2016). Special education and general education preservice teachers' co-teaching experiences: A comparative synthesis of qualitative research. International Journal of Inclusive Education, 20(1), 91-107.

Spear-Swerling, L. (2009). A literacy tutoring experience for prospective special educators and struggling second graders. Journal of Learning Disabilities, 42, 431-443.

Sweigart, C. A., Landrum, T. J., \& Pennington, R. C. (2015). The effect of real-time visual performance feedback on teacher feedback: A preliminary investigation. Education and Treatment of Children, 38, 429-450.

Vadasy, P. F., \& Sanders, E. A. (2008). Benefits of repeated reading intervention for low-achieving fourth- and fifth-grade students. Remedial and Special Education, 29(4), 235-249.

Vaughn, S., Denton, C. A., \& Fletcher, J. M. (2010). Why intensive interventions are necessary for students with severe reading difficulties. Psychology in the Schools, 47(5), 432-444.

Wolff, C. E., Jarodzka, H., \& Boshuizen, H. P. (2017). See and tell: Differences between expert and novice teachers' interpretations of problematic classroom management events. Teaching and Teacher Education, 66, 295-308.

Wozencroft, A. J., Pate, J. R., \& Griffiths, H. K. (2015). Experiential learning and its impact on students' attitudes toward youth with disabilities. Journal of Experiential Education, 38(2), 129-143.
Yang, S. H. (2009). Using blogs to enhance critical reflection and community of practice. Journal of Educational Technology \& Society, 12(2), 11-21.

Zeichner, K. (2012). The turn once again toward practice-based teacher education. Journal of Teacher Education, 63, 376-382.

Zeichner, K., \& Liu, K. Y. (2010). A critical analysis of reflection as a goal for teacher education. In N. Lyons (Ed.) Handbook of reflection and reflective inquiry (pp. 6784). Boston, MA: Springer. 